\title{
Analisis Sebaran Spasial Kerentanan Longsor Sebagai Upaya Mitigasi Bencana di Kecamatan Berastagi Kabupaten Karo Provinsi Sumatera Utara
}

\author{
Dinda Ayu Pertiwi Sitorus ${ }^{1}$, Slamet Bejo $^{2}$, Said Muzambiq ${ }^{3}$ \\ ${ }^{1}$ Jurusan Pengelolaan Sumberdaya Alam, Fakultas Sekolah Pascasarjana, Universitas Sumatera Utara, Kampus USU \\ Padang Bulan Medan 20155, Indonesia. \\ ${ }^{2}$ Jurusan Kehutanan, Fakultas Kehutanan, Universitas Sumatera Utara, Kampus USU Padang Bulan \\ Medan 20155, Indonesia. \\ ${ }^{3}$ Jurusan Teknik Lingkungan, Fakultas Teknik, Universitas Sumatera Utara, Kampus USU Padang Bulan \\ Medan 20155, Indonesia. \\ Koresponden email: dindasitorus7@gmail.com
}

Diterima: 20 April 2021

Disetujui: 31 Mei 2021

\begin{abstract}
Kabupaten Karo has several areas that have the potential to the occurrence of landslide. Hence , landslide disaster mitigation is very important because it has negative effects in the long run for mankind and the environment. This study attempts to analyze the distribution of vulnerability landslide in Berastagi mitigation and management and provide the right environment.The causes of a movement happen landslides in Berastagi is the condition of a steep slope around 35, 55\% - percent building material lithology / material unstable among other breccia volcanic and, riodasit tufa and the triggering factor of rainfall and infiltarsiwater. The research method was descriptive method, whereas scoring using Shapefile (SHP) data in 2019 based on the 2004 Puslittanak. The results of the field are the weightings of the respective parameter with overlay uses software arcgis 10.6.The result showed that the DouluVillage, SempaJayaVillage, Raya Village, as well as Tambak Lau Mulgap II intheBerastagi District have a high vulnerability to landslides. Hence, calamity mitigation recommendations, through erosion revegetasi including through the planting of crops.
\end{abstract}

Keywords: Berastagi District, vulnerability, mitigation, landslides, Arcgis 10.6

\begin{abstract}
Kabupaten Karo memiliki beberapa wilayah yang berpotensi untuk terjadinya longsor oleh sehingga mitigasi bencana longsor sangat diperlukan untuk mencegah dampak buruk dalam jangka panjang bagi manusia dan lingkungan. Penelitian bertujuan menganalisis sebaran kerawanan longsor di Kecamatan Berastagi serta memberikan mitigasi dan pengelolaan lingkungan yang tepat. Banyak faktor yang menyebabkan terjadinya pergerakan longsor di kawasan Berastagi, antara lain kondisi kemiringan lereng antara 35\% sampai 55\%, litologi / material penyusun yang tidak stabil, antara lain breksi vulkanik dan tufa riodasit, serta faktor pemicu curah hujan dan infiltrasi air. Metode penelitian yang dilakukan adalah metode deskriptif, skoring dengan menggunakan data Shapefile tahun 2019 berdasarkan Puslittanak 2004.Selanjutnya data hasil lapangan diberi pembobotan masing-masing parameter dengan overlay menggunakan software Arcgis 10.6. Hasil penelitian menunjukkan bahwa Desa Doulu, Desa Sempa Jaya, Desa Raya, dan Tambak Lau Mulgap II di Kecamatan Berastagi mempunyai luasan kerentanan longsor yang sangat tinggi. Rekomendasi mitigasi bencana tanah longsor yang dilakukan, diantaranya dengan cararevegetasi tanaman pada lereng lereng yang gundul, mengubah geometri lereng, membuat perlindungan hidrologi kawasan dan membuat dinding penahan dari batuan dan parit permukaan lereng yang tidak stabil.
\end{abstract}

Kata Kunci: Kecamatan Berastagi, kerentanan, mitigasi, longsor, Arcgis 10.6

\section{Pendahuluan}

Pergerakan batuan atau tanah dalam skala besar yang disebabkan oleh gravitasi merupakan pengertian dari pergerakan longsor yang dapat menimbulkan banyak korban jiwa atau kerugian harta benda [1]. Pergerakan tanah yang terjadi disebabkan oleh faktor pengendali dan pemicunya secara alami dan tidak alami, dalam beberapa kasus, dapat menyebabkan bencana bagi pergerakan tanah. Bencana pergerakan tanah atau longsor sering terjadi karena bencana tersebut dapat merusak berbagai prasarana Infrastruktur dan menimbulkan banyak kerugian baik ekonomi maupun korban jiwa, sehingga bencana 
tersebut sangat merugikan [2][3][4].

Tanah longsor didefinisikan sebagai pergerakan massa batuan, puing-puing, atau tanah yang jatuh menuruni lereng. Tanah longsor adalah jenis pembuangan massa secara besar, yang menunjukkan setiap gerakan tanah dan batuan di bawah pengaruh langsung gravitasi. Istilah longsor mencakup limatipepergerakan lereng, yaitu jatuh, terguling, longsor, menyebar, dan mengalir. Selanjutnya dibagi lagi dengan jenis bahan geologi (batuan dasar, puing, atau tanah). Aliran puing (biasa disebut sebagai semburan lumpur atau lumpur longsor) dan batuan yang jatuh adalah contoh jenis longsor yang umumnya terjadi.

Longsor merupakan masalah yang tak kunjung usai pada musim hujan di perbukitan, sebagian besar lahan terserap terlepas dari lokasi aslinya dan mengalir ke bawah perbukitan sehingga menimbulkan kerugian dan gangguan terhadap kehidupan dan harta benda masyarakat [5]. Berbagai model telah dirancang untuk menilai kerentanan longsor.Kajian ini diujicobakan dalam menilai kerentanan longsor di wilayah studi dengan mengintegrasikan pengaruh berbagai parameter yang mempengaruhi jenis tanah.

Secara geografis letak Kabupaten Karo berada diantara $2^{\circ} 50^{\prime}-3^{\circ} 19^{\prime}$ LU dan $97^{\circ} 55^{\prime}-98^{\circ} 38^{\prime}$, BT dengan luas $2.127,25 \mathrm{Km}^{2}$. Pada wilayah ini banyak ditemui lembah lembah dan lereng lereng bukit yang curam/terjal, berada pada ketinggian 200-1500 mdpl, diapit oleh dua gunung berapi aktif dan berada pada dataran tinggi bukit barisan dengan kondisi topografi yang berbukit dan bergelombang, sehingga tidak menutup kemungkinan terjadinya bencana tanah longsor.

Kecamatan Berastagi, Kabupaten Karo, Sumatera Utara merupakan salah satu wilayah yang perkembangan sarana infrastrukturnya cukup tinggi dan mempunyai potensi terjadinya gerkan tanah/longsor. Hal tersebut diperkuat berdasarkan informasi dari Badan Geologi Pusat Vulkanologi dan Mitigasi Bencana Geologi Kabupaten Karo memiliki beberapa wilayah yang berpotensi untuk terjadinya longsor. Oleh karena itu perlu dilakukan mitigasi longsor, karena longsor memiliki dampak negatif jangka panjang bagi manusia dan lingkungan [6].

\section{Metode Penelitian}

Analisis sebaran spasialkerentananlongsor dilakukan dengan menyusun berbagai macam data Shapefile (shp)kemiringan lereng, jenis batuan, curah hujan, jenis tanah dan penggunaan lahan secara terperinci, kemudian menggabungkan dan memberi bobot masing-masing parameter dengan overlay menggunakan software Arcgis 10.6. Maka akan didapatkan klasifikasi tingkat kerawanan longsor. Berdasarkan puslittanak 2004 dibagi menjadi beberapa nilai dalam masing-masing parameternya, yaitu $30 \%$ untuk curah hujan, 20\% untuk kemiringna lereng, jenis batuan dan penggunaan lahan serta $10 \%$ pada jenis tanah.Untuk itu adapun rumus yang digunakan:

Keterangan:

$$
\mathrm{SKOR} \text { TOTAL }=0.3 \mathrm{FCH}+0.2 \mathrm{FKL}+0.2 \mathrm{FBD}+0.2 \mathrm{FPL}+0.1 \mathrm{FJT}
$$

$\mathrm{FCH}=$ Faktor Curah Hujan

FKL $=$ Faktor Kemiringan Lereng

FBD = Faktor Jenis Batuan

FPL = Faktor Penutupan Lahan

FJT $=$ Faktor Jenis Tanah

0,$3 ; 0,2 ; 0,1=$ Bobot nilai

Klasifikasi akhir, hasil analisis skor dilakukan dengan memberikan tingkat kepekaan terhadap longsor (rendah, sedang, tinggi, sangat tinggi). Kisaran peringkat ditentukan berdasarkan skor total akhir, dan semakin tinggi skornya, semakin tinggi kerentanannya:

$$
\frac{\text { Skor tertinggi - Skor Terendah }}{\text { Jumlah kelas Klasifikasi }}
$$

\section{Hasil dan Pembahasan Kemiringan lereng}

Kemiringan lereng di Kecamatan Berastagi bervariasi mulai dari sangat curam hingga datar. Mengacu pada klasifikasi Puslittanak (2004), Kecamatan Berastagi memiliki lima klasifikasi kemiringan lereng antara lain $>45^{\circ}$ berarti sangat curam, $30^{\circ}-45^{\circ}$ curam, $15^{\circ}-30^{\circ}$ agak curam, $8^{\circ}-15^{\circ}$ landai, dan $>8^{\circ}$ datar. Umumnya Kecamatan Berastagi di dominansi oleh kemiringan lereng yang datar, dengan jumlah luasan daerah yang berada pada kemiringan $>8 \%$ dari seluruh Kecamatan Berastagi adalah 1280,38 Ha. 
Sebaran kemiringan lereng yang sangat curam merata pada tiap desa, dari hasil digitasi peta setiap desa memiliki daerah yang datar hingga sangat curam. Luasan daerah yang sangat curam adalah sebesar 354,61 Ha, akan tetapi daerah terluas yang memiliki tingkat kemiringan lereng yang sangat curam berada pada Desa Doulu. Kemiringan lereng yang curam maupun sangat curam dapat mempengaruhi kestabilan suatu lereng, dimana keadaan tersebut akan menghasilkan kecepatan aliran air bagian atas sebagai tinggi dan mengakibatkan abrasi lebih intensif dibanding daerah yang landai, banyaknya dijumpai singkapan mengakibatkan proses pelapukan yg lebih cepat. Batuan yang lapuk memiliki kekuatan yang rendah sebagai akibatnya keamanan lereng menjadi berkurang.

Kecepatan aliran air permukaan menjadi tinggi dan mengakibatkan pengikisan lebih intensif dibanding daerah yang landai, banyaknya dijumpai singkapan menyebabkan proses pelapukan yang lebih cepat.Batuan yang lapuk mempunyai kekuatan yang rendah sehingga keamanan lereng menjadi berkurang.

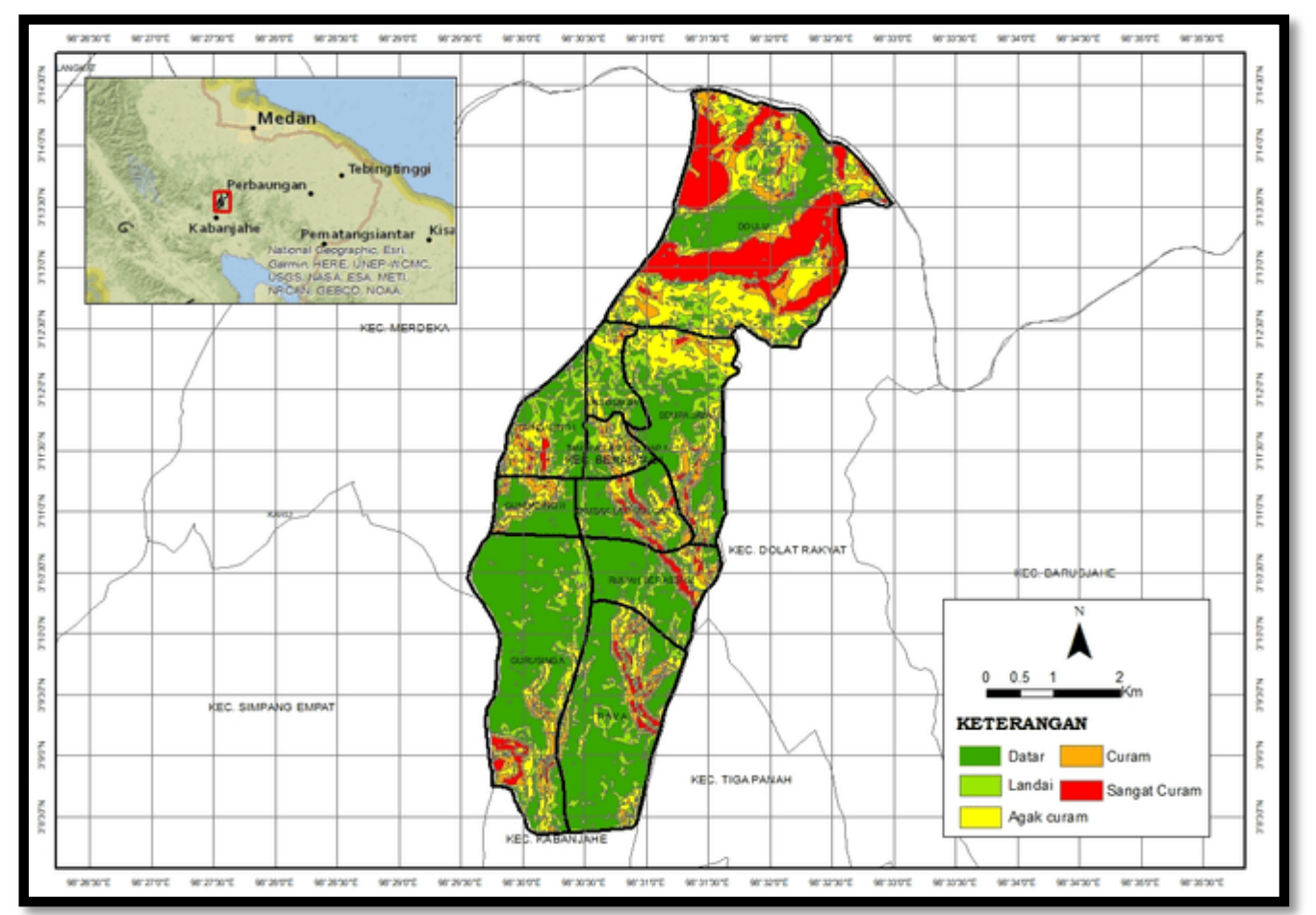

Gambar1. Peta kemiringan lereng Kecamatan Berastagi Sumber: Pengolahan data (2021)

Tabel 1. Luas area kemiringan lereng Kecamatan Berastagi

\begin{tabular}{lll}
\hline Lereng & Klasifikasi & Luas (Ha) \\
\hline $0-8 \%$ & Datar & 1280,38 \\
$8-15 \%$ & Landai & 481,11 \\
$15-30 \%$ & Agak curam & 599,88 \\
$30-45 \%$ & Curam & 302,49 \\
$>45 \%$ & Sangat Curam & 354,61 \\
\hline Total & Sumber: Pengolahan data (2021) \\
\hline
\end{tabular}

\section{Jenis Tanah}

Jenis tanah di Kecamatan Berastagi terbagi menjadi tiga kelas, yaitu Podsolik, Latosol, dan Andosol. Jenis tanah podsolik dan andosol merupakan tanah yang peka terhadap erosi dengan permeabilitas lambat.Sementara latosol tanah yang agak peka terhadap erosi dengan permeabilitas cepat, distribusi spasial jenis tanah di lokasi penelitian.

Secara umum Kecamatan Berastagi di dominasi oleh jenis tanah Andosol, dimana tanah ini memiliki ciri fisik dengan warna gelap kecokelatan terutama pada horizon humus dengan struktur lemah, terlihat lebih gembur, kadar bahan organik tinggi, dan terasa licin saat berada ditangan. Secara definisi tanah andosol berarti jenis tanah yang berwarna hitam sedangkan menurut ilmu tanah, tanah yang 
berwarna hitam adalah tanah vulkasnis yang berasal dari gunung api, umumnya tanah jenis andosol lebih rentan terhadap longor. Berdasarkan gambar 2 dapat dilihat bahwa Jenis tanah andosol merupakan jenis tanah yang terdapat pada tiap desa ditandi dengan warna coklat muda dengan luas sebesar 2325,88 Ha. Jenis tanah Andosol Podsolik Cokelat hanya terdapat pada Desa Gurusinga ditandai dengan warna hijau kecoklatan dengan luas 24,38 Ha. Sementara jenis tanah Andosol Litosol berada pada Desa Doulu dan Desa Sempa jaya ditandai dengan warna merah gelap dengan luas wilayah sebesar 668,19 Ha.

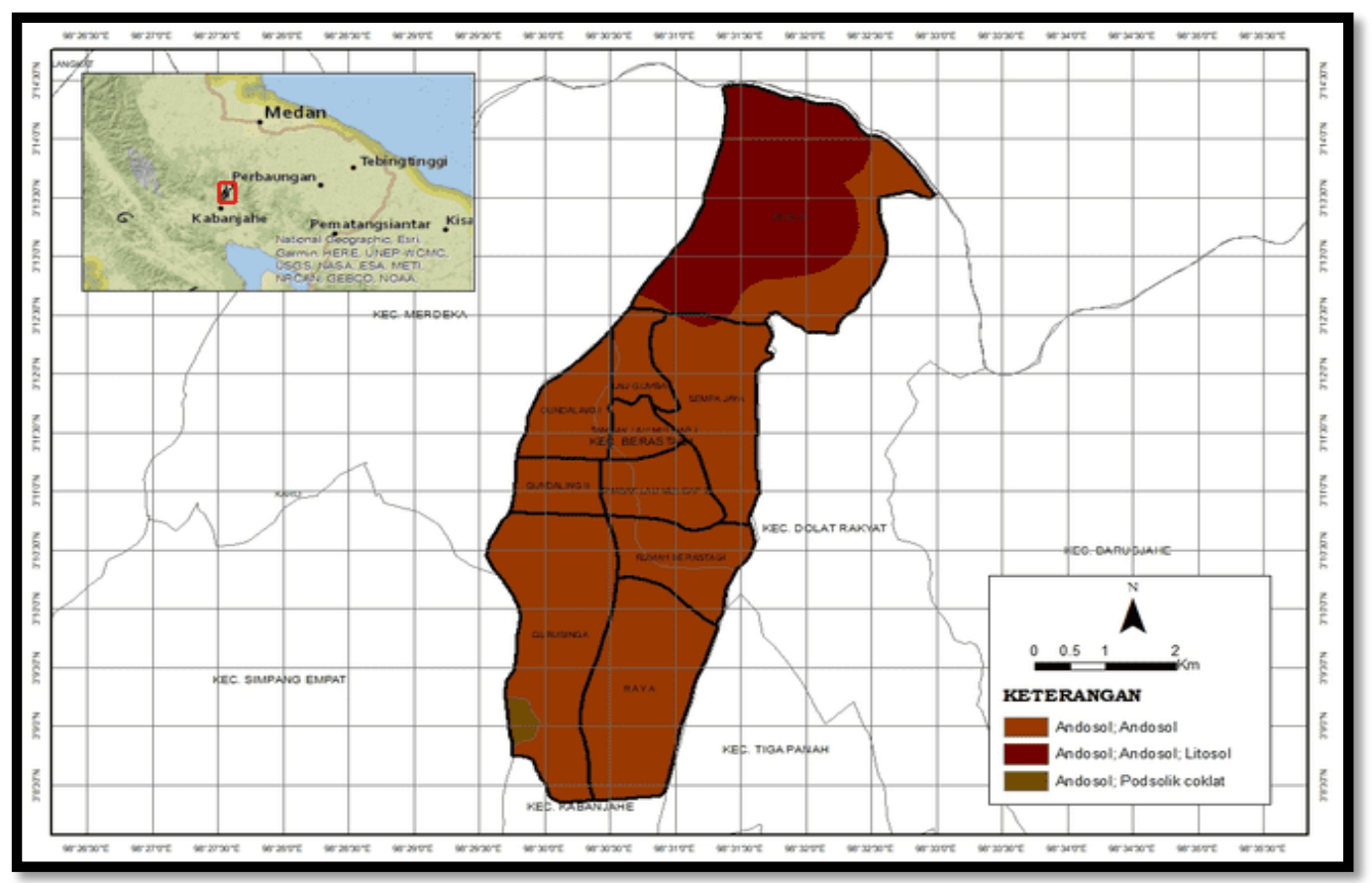

Gambar 2. Peta jenis tanah Kecamatan Berastagi Sumber: Pengolahan data (2021)

Tabel 2. Luasan jenis tanah Kecamatan Berastagi

\begin{tabular}{|c|c|c|c|c|}
\hline \multirow[b]{2}{*}{ Desa } & \multicolumn{3}{|c|}{ Jenis Tanah $(\mathrm{Ha})$} & \multirow[b]{2}{*}{ Total } \\
\hline & Andosol & Andosol; Litosol & $\begin{array}{c}\text { Andosol; } \\
\text { Podsolikcoklat }\end{array}$ & \\
\hline Doulu & 254,2 & 659,79 & & 913,99 \\
\hline Gundaling I & 165,95 & & & 165,95 \\
\hline Gundaling II & 104,3 & & & 104,3 \\
\hline Gurusinga & 509,12 & & 24,38 & 533,51 \\
\hline Lau Gumba & 94,37 & & & 94,37 \\
\hline Raya & 433,65 & & & 433,65 \\
\hline Rumah Berastagi & 200,58 & & & 200,58 \\
\hline Sempa Jaya & 332,89 & 8,4 & & 341,29 \\
\hline Tambak Lau Mulgap I & 71,11 & & & 71,11 \\
\hline Tambak Lau Mulgap II & 159,67 & & & 159,67 \\
\hline Total & 2325,88 & 668,19 & 24,38 & 3018,47 \\
\hline
\end{tabular}

Sumber: Pengolahan data (2021)

\section{Penggunaan Lahan}

Berdasarkan hasil digitasi peta penggunaan lahan Kecamatan Berastagi memiliki tiga tipe yang mana tiap lahan yang digunakan memiliki kontribusi yang berbeda-beda. Mengacu pada Puslittanak terdapat beberapa penggunaan lahan di Kecamatan Berastagi terbagi atas tiga, yaitu hutan lahan kering skunder, pertanian lahan kering, dan semak belukar. Pemanfaatan lahan dapat menjadi faktor pengontrol gerakan tanah dan meningkatkan resiko gerakan tanah karena pemanfaatan lahan akan berpengaruh pada tutupan lahan yang ada. Suatu vegetasi penutup tanah yang baik seperti rumput yang tebal atau rimba yang lebat akan menghilangkan pengaruh hujan dan topografi terhadap longsor [7].

Penggunaan lahan dengan luas terbesar adalah pertanian lahan kering sebesar 2275,61 Ha yang berada pada tiap desa di Kecamatan Berastagi, dalam hal ini Desa Doulu memiliki penggunaan lahan yang berbeda dibandingkan dengan desa lainnya, terdapat hutan lahan kering sekunder, pertanian lahan 
kering, dan semak belukar dengan masing masing luasan sebesar 527,9 Ha; 187,4 Ha; 197,5 Ha yang terlampir pada Tabel 3.

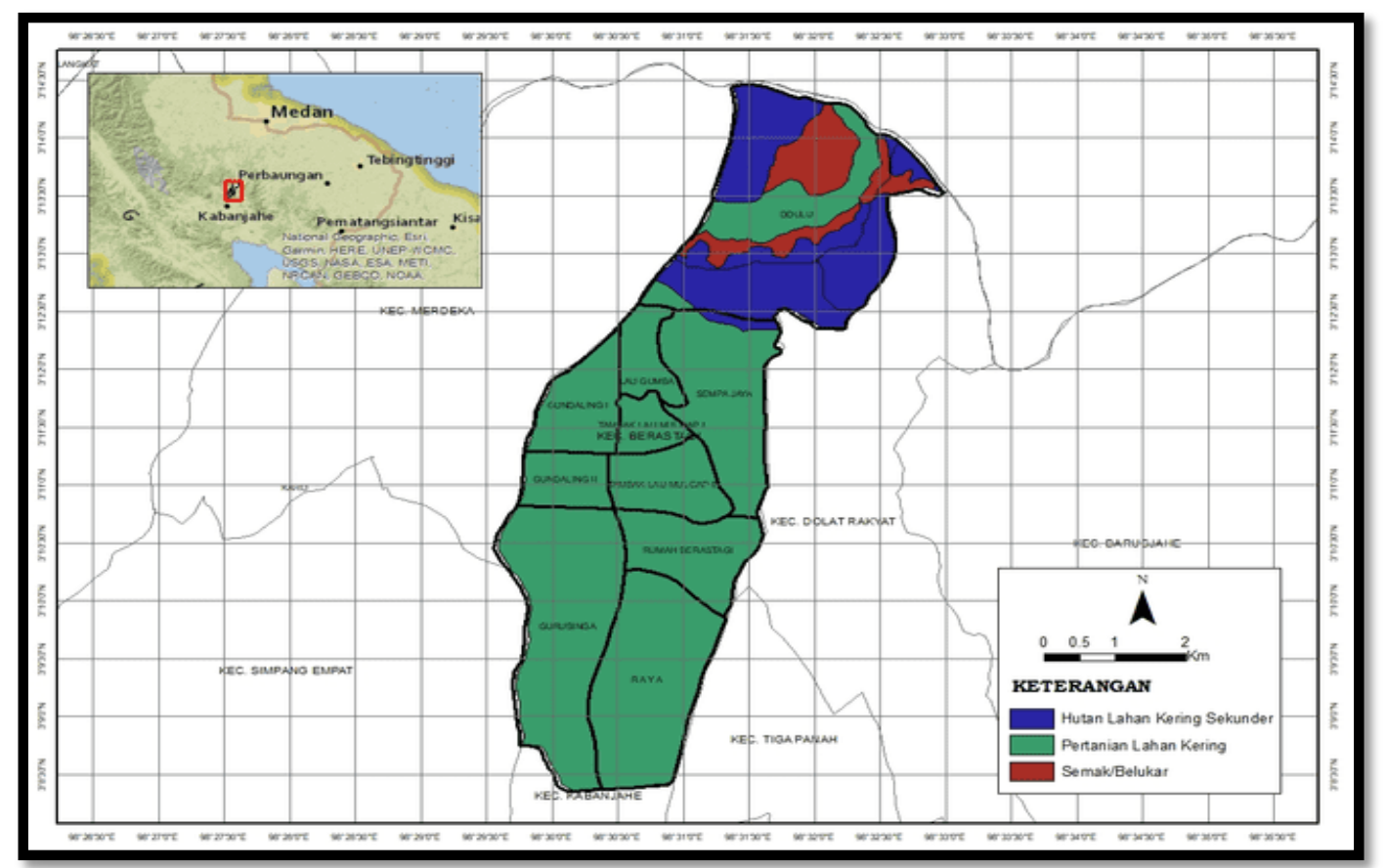

Gambar 3. Peta penggunaan lahan kecamatan Berastagi Sumber: Pengolahan data (2021)

Tabel 3. Luasan area penggunaan lahan Kecamatan Berastagi

\begin{tabular}{|c|c|c|c|c|}
\hline \multirow[b]{2}{*}{ Total } & \multicolumn{3}{|c|}{ Penggunaan Lahan (Ha) } & \multirow[b]{2}{*}{ Total } \\
\hline & $\begin{array}{l}\text { Hutan Lahan Kering } \\
\text { Sekunder }\end{array}$ & $\begin{array}{l}\text { Pertanian Lahan } \\
\text { Kering }\end{array}$ & $\begin{array}{l}\text { Semak/ } \\
\text { Belukar }\end{array}$ & \\
\hline Doulu & 527,92 & 187,47 & 197,57 & 912,97 \\
\hline Gundaling I & & 162,07 & & 162,07 \\
\hline Gundaling II & & 103,88 & & 103,88 \\
\hline Gurusinga & & 517,03 & & 517,03 \\
\hline Lau Gumba & & 95,03 & & 95,03 \\
\hline Raya & & 440,73 & & 440,73 \\
\hline Rumah Berastagi & & 204,23 & & 204,23 \\
\hline Sempa Jaya & 17,35 & 330,14 & & 347,50 \\
\hline Tambak Lau Mulgap I & & 72,40 & & 72,40 \\
\hline Tambak Lau Mulgap II & & 162,57 & & 162,57 \\
\hline Total & 545,28 & 2275,61 & 197,57 & 3018,47 \\
\hline
\end{tabular}

\section{Curah Hujan}

Curah hujan yang terjadi di Kecamatan Berastagi termasuk kategori tinggi bahkan sangat tinggi, berkisar antara 2000-4000 mm/tahun. Mengacu pada Puslittanak 2004, intensitas curah hujan di Kecamatan Berastagi terbagi atas tiga kategori yaitu curah hujan sedang dengan intensitas 2000-2500 $\mathrm{mm} /$ tahun berada pada Desa Gurusinga dan Raya. Curah hujan basah dengan intensitas 2500-3000 $\mathrm{mm} /$ tahun terjadi pada tiap desa di Kecamatan Berastagi, curah hujan sangat basah dengan intensitas $>3000$ terjadi pada Desa Doulu dengan luas area 102,53Ha. Curah hujan yang tinggi sangat berpengaruh terhadap kadar air dan kejenuhan air sehingga air hujan yang turun menjadi pemicu terjadinya longsor.

Berdasarkan curah hujan yang relatif tinggi pada tiap desa di Kecamatan Berastagi dapat menjadikan daerah tersebut akan rawan longsor. Luasan area yang memiliki curah hujan tertinggi berada pada Desa Doulu dan Sempa Jaya. 


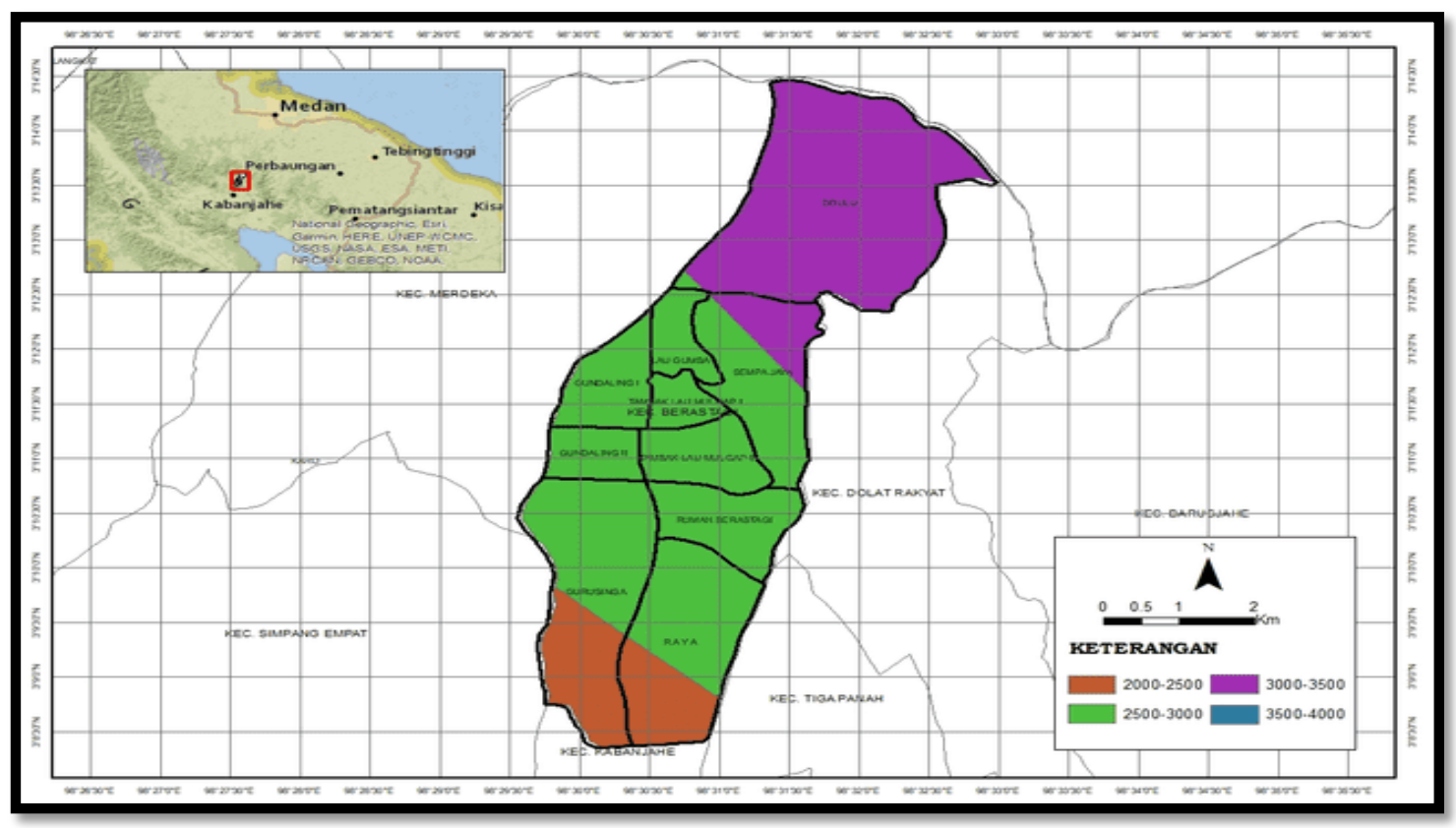

Gambar 4. Peta curah hujan Kecamatan Berastagi Sumber: Pengolahan data (2021)

Tabel 4. Luas area curah hujan Kecamatan Berastagi

\begin{tabular}{|c|c|c|c|c|c|}
\hline \multirow{2}{*}{ Desa } & \multicolumn{4}{|c|}{ Curah Hujan (mm/tahun) } & \multirow[b]{2}{*}{ Total } \\
\hline & $2000-2500$ & $2500-3000$ & $3000-3500$ & $3500-4000$ & \\
\hline Doulu & & 6,64 & 912,63 & 1,85 & 921,14 \\
\hline Gundaling I & & 161,44 & & & 161,44 \\
\hline Gundaling II & & 103,48 & & & 103,48 \\
\hline Gurusinga & 198,31 & 316,72 & & & 515,03 \\
\hline Lau Gumba & & 94,62 & 0,04 & & 94,66 \\
\hline Raya & 156,02 & 283,00 & & & 439,02 \\
\hline Rumah Berastagi & & 203,44 & & & 203,44 \\
\hline Sempa Jaya & & 236,15 & 109,99 & & 346,15 \\
\hline Tambak Lau Mulgap I & & 72,12 & & & 72,12 \\
\hline Tambak Lau Mulgap II & & 161,94 & & & 161,94 \\
\hline Total & 354,33 & 1639,60 & 1022,67 & 1,85 & 3018,47 \\
\hline
\end{tabular}

\section{Jenis Batuan}

Secara geologi, lokasi penelitian merupakan wilayah yang formasi batuannya sangat dipengaruhi oleh Gunung Sibayak, dan karakteristik teknisnya berbeda-beda tergantung dari tempat asalnya. Secara umum spesifikasi batuan di pengaruhi oleh kandungan mineral, kekar/ bentuk gabungan lapisan bidang dasar, struktur dan tekstur, sedimentasi/ rekatan dan kondisi cuaca.

Kecamatan Berastagi memiliki dua jenis formasi batuan yang terdiri dari batuan vulkanik dan batuan aluvial. Formasi batuan vulkanik terbagi atas tiga jenis, yaitu Formasi gunung api Barus Satuan Sibayak (Qvba), Satuan Takur dengan simbol (QTvk), dan Satuan Singkut (Qvbs), sedangkan alluvial yang terdapat dilokasi penelitian adalah satuan alluvium dengan symbol (Qh). Formasi batuan vulkanik satuan singkut (Qvbs) merupakan jenis batuan yang terdapat pada tiap Desa dengan luas area sebesar 245,89 Ha. Ini merupakan jenis batuan yang sangat besar sebarannya, sedangkan formasi batuan vulkanik satuan takur-takur (QTvk) merupakan jenis batuan yang paling sedikit sebarannya dengan jumlah luasan $133,27 \mathrm{Ha}$. 


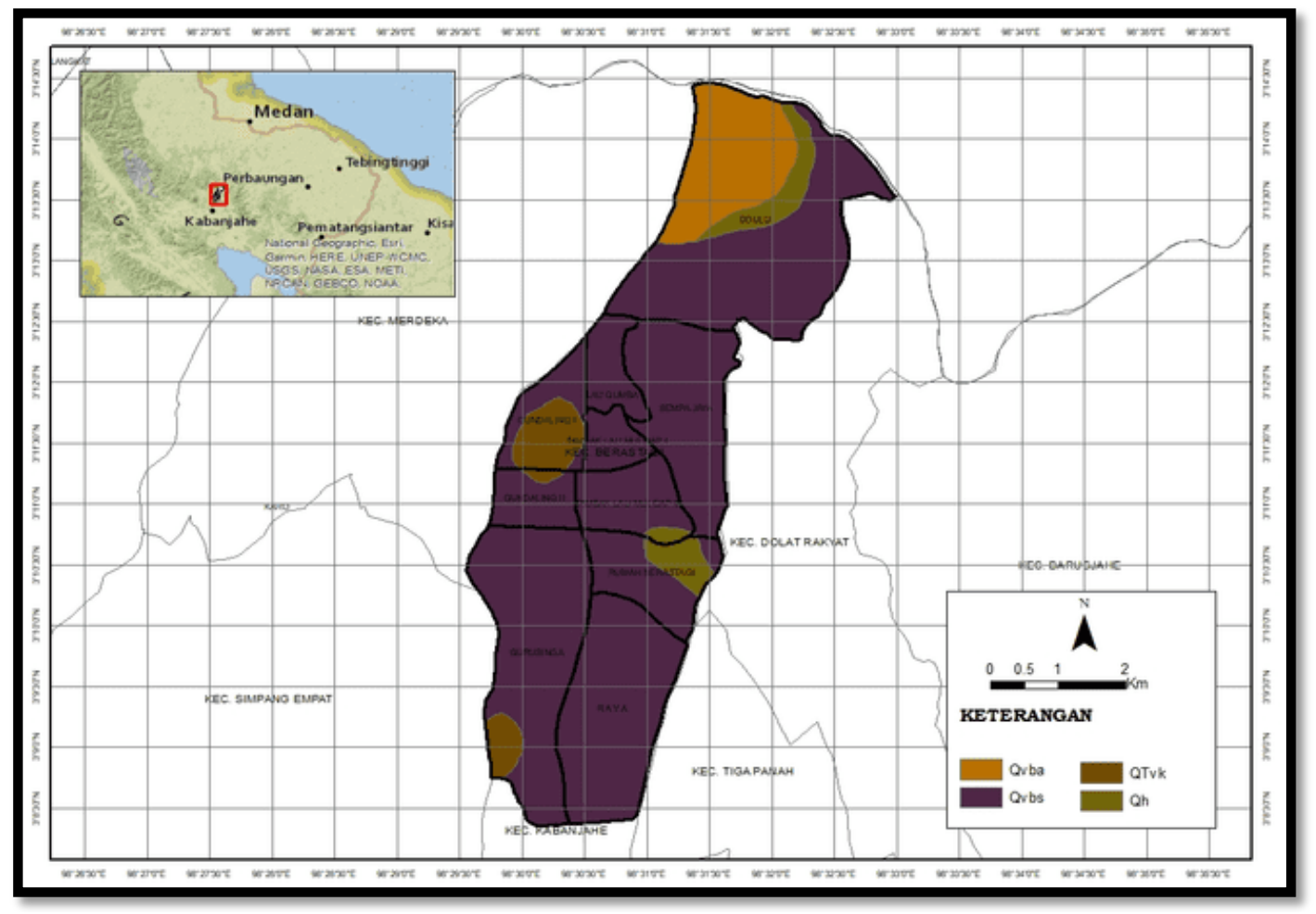

Gambar 5. Peta jenis batuan Kecamatan Berastagi Sumber: Pengolahan data (2021)

Tabel 5. Luasan jenis batuan Kecamatan Berastagi

\begin{tabular}{llllll}
\hline \multirow{2}{*}{ Desa } & \multicolumn{2}{l}{ Batuan (Ha) } & & \multirow{2}{*}{ Total } \\
\cline { 2 - 4 } & Qh & QTvk & Qvba & Qvbs & \\
\hline Doulu & 78,65 & & 289,79 & 545,54 & 913,99 \\
Gundaling I & & 85,64 & & 80,31 & 165,95 \\
Gundaling II & & 8,42 & & 95,87 & 104,30 \\
Gurusinga & & 39,24 & & 494,31 & 533,51 \\
Lau Gumba & & & 94,37 & 94,37 \\
Raya & & & 433,65 & 433,65 \\
Rumah Berastagi & 51,19 & & & 149,39 & 200,58 \\
Sempa Jaya & 0,47 & & 340,82 & 341,29 \\
Tambak Lau Mulgap I & & & 71,11 & 71,11 \\
Tambak Lau Mulgap II & 12,17 & & & 147,49 & 159,67 \\
\hline Total & 142,50 & 133,27 & 289,79 & 2452,89 & 3018,47 \\
\hline
\end{tabular}

Keterangan: Qh: Batuan Aluvial Satuan Aluvium Muda, QTvk: Batuan Vulkanik Satuan takur-takur, Qvba: Batuan Vulkanik Satuan Sibayak, Qvbs: Batuan Vulkanik Satuan singkut.

Sumber: Pengolahan data (2021)

\section{Analisis Sebaran Spasial Kerawanan Longsor}

Sebaran kerawanan longsor pada Kecamatan Berastagi terdiri atas empat kelas yaitu rendah, sedang, tinggi dan sangat tinggi. Sebaran wilayah longsor cenderung merata pada tiap desa yang artinya tiap desa di Kecamatan Berastagi berpotensi terjadinya longsor. Kecamatan Berastagi berpotensi terjadinya gerakan tanah longsor dengan kelas kerawanan sangat tinggi sebesar $18 \%$ dari total luas Kecamatan Berastagi yaitu dengan nilai 47,9947 Ha dari 270,3858 Ha. Sebaran rawan longsor terluas terjadi pada Desa Sempa jaya, Desa Doulu, dan Desa Tambak Lau Mulgap II, dibuktikan dengan hasil analisis parameter kerawanan longsor dapat dilihat dari segi kemiringan lereng pada desa tersebut sangat tinggi. Begitu pula dengan curah hujan yang terjadi pada desa ini juga memiliki intensitas yang tinggi berkisar antara 3000-4000 $\mathrm{mm} /$ tahun, sehingga menyebabkan tingginya kerawanan longsor yang dapat terjadi pada daerah tersebut.

Potensi gerakan tanah longsor dengan tingkat kerawanan tinggi dan sedang juga memiliki nilai yang hampir sama sebesar 31\% dari total luas Kecamatan Berastagi adapun nilai luas kerawanan longsor yang tinggi yaitu 84,5191 Ha, sedangkan potensi gerakan tanah longsor dengan tingkat kerawanan rendah sebesar 20\% dari total luas kecamatan Berastagi yaitu dengan nilai 54,0458 Ha. Jika dilihat dari 
pemukiman masyarakat pada Gambar 6, umumnya pemukiman masyarakat berada pada sebaran kerawanan longor dengan kelas rendah dan sedang. Hanya beberapa desa yang terdapat pemukiman dalam sebaran kerawanan longor dengan kelas yang tinggi yaitu Desa Lau Gumba dan Tambak Lau Mulgap I, untuk itu penulis melakukan survei lapangan guna melakukan pengujian kestabilan lereng.

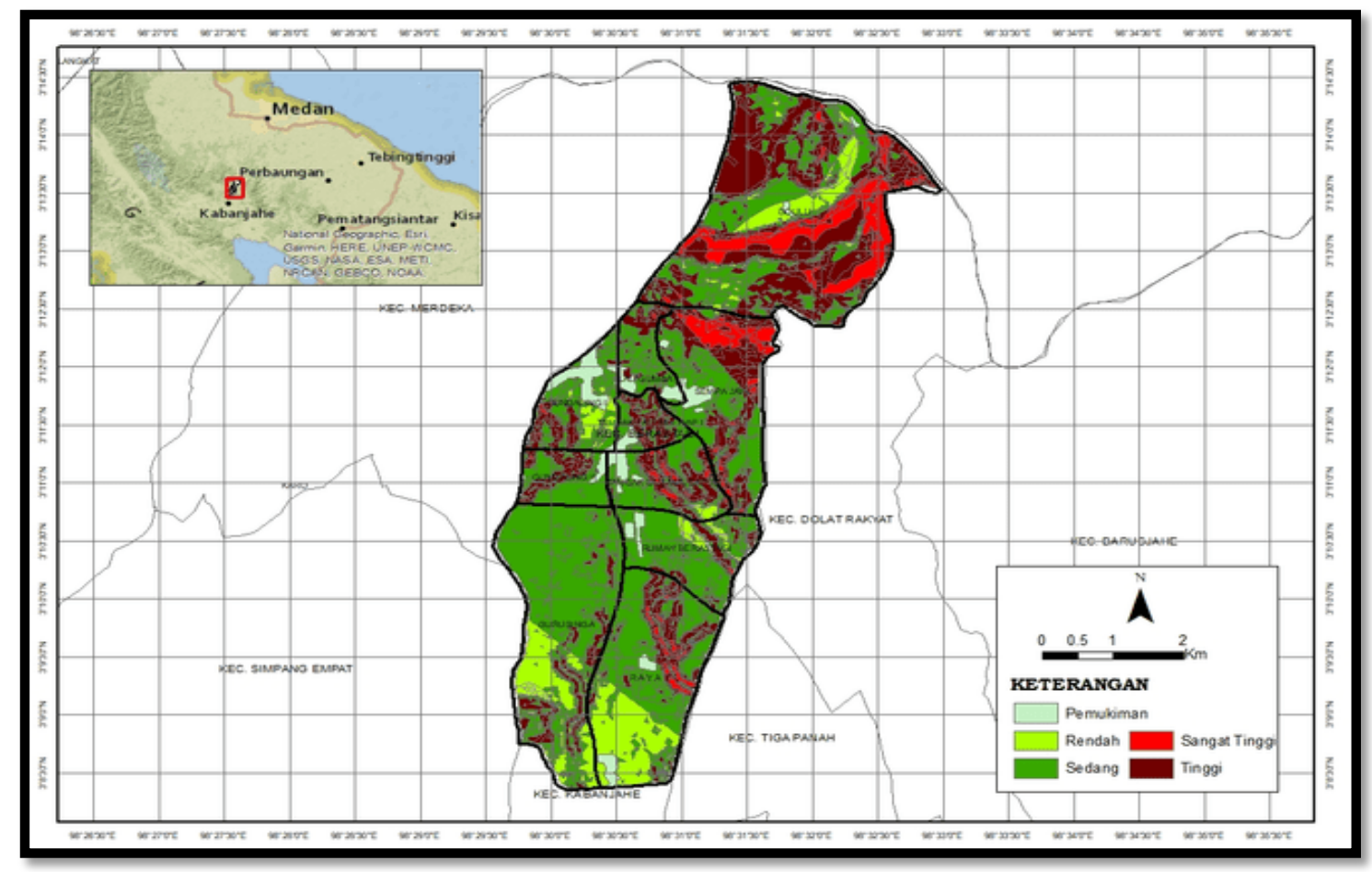

Gambar 6. Peta Rawan Longsor di Kecamatan Berastagi Sumber: Pengolahan data (2021)

Berdasarkan hasil survei lapangan Desa Tambak Laumulgap I merupakan desa yang memiliki morfologi curam, dimana desa tersebut berada pada lembah atau cekungan yang memiliki lereng lereng terjal, oleh karena itu penulis memutuskan untuk melakukan pengujian kestabilan lereng pada desa ini. Kerawanan longsor pada desa ini terbagi menjadi tiga kelas yaitu, sedang, tinggi, dan sangat tinggi. Luas area yang berada pada kelas rawan longsor yang tinggi sebesar 35,04 Ha, area rawan longsor yang sedang sebesar 37,86 Ha sedangkan luas area rawan longsor yang sangat tinggi sebesar 0,64 Ha. Beberapa lereng pada lokasi ini juga pernah bahkan sering terjadi longsor, baik skala besar maupun kecil. Pemicu terbesar adalah curah hujan dan kurangnnya vegetasi pada tiap lereng yang ada, serta penambahan beban pada puncak lereng.

Tabel 6. Luasan area kerawanan longsor per desa di Kecamatan Berastagi

\begin{tabular}{llllll}
\hline \multirow{2}{*}{ Desa } & \multicolumn{5}{c}{ Kelas Kerawanan Longsor (Ha) } \\
\cline { 2 - 5 } & Rendah & Sedang & Tinggi & $\begin{array}{c}\text { Sangat } \\
\text { Tinggi }\end{array}$ \\
\hline Doulu & 68,78 & 268,42 & 422,24 & 151,89 & 911,35 \\
Gundaling I & 27,69 & 102,56 & 32,07 & 0,82 & 163,16 \\
Gundaling II & 0,49 & 73,11 & 31,22 & 0,55 & 105,39 \\
Gurusinga & 89,39 & 377,33 & 58,28 & & 525,01 \\
Lau Gumba & & 67,62 & 28,26 & 0,58 & 96,47 \\
Raya & 119,20 & 227,96 & 73,53 & 15,79 & 436,50 \\
Rumah Berastagi & 17,07 & 160,43 & 22,08 & 1,46 & 201,06 \\
Sempa Jaya & 0,83 & 168,93 & 118,71 & 52,04 & 340,52 \\
Tambak Lau Mulgap I & & 37,86 & 35,04 & 0,67 & 73,59 \\
Tambak Lau Mulgap II & 5,79 & 97,99 & 52,06 & 9,52 & 165,38 \\
\hline Total & 329,28 & 1582,26 & 873,54 & 233,37 & 3018,47 \\
\hline
\end{tabular}

\section{Mitigasi Bencana}

Sumber: Pengolahan data (2021)

Mitigasi merupakan kegiatan yang dilakukan sebelum terjadi bencana untuk mengurangi dan mencegah dampak yang ditimbulkan. Berdasarkan dari data dan hasil penelitan seluruh desa di 
Kecamatan Berastagi memiliki wilayah yang berpotensi terjadinya longsor, terutama pada Desa Doulu, Desa Sempa Jaya, Desa Lau Gumba, Desa Tambak Lau Mulgap II, dan Desa Rumah Berastagi dengan jumlah luasan area yang berpotensi longsor sangat tinggi seluas 233,37 Ha. Oleh karena itu perlu dilakukan mitigasi bencana baik bersifat struktural maupun non structural, mitigasi sebaiknya dilakukan oleh pemerintah dan masyarakat, berguna untuk melindungi masyarakat yang bertempat tinggal di kawasan atau daerah yang rawan longsor serta meningkatkan kesadaran masyarakat terhadap potensi dan bahay longsor.

Mitigasi struktural yang dapat dilakukan seperti pemetaan rawan longsor pada Kecamatan Berastagi. Hal ini berguna untuk mengetahui sebaran rawan longsor di Kecamatan Berastagi. Lalu perlunya dilakukan pemasangan EWS di sekitar pemukiman masyarakat yang berada pada kawasan rawan longsor. Pemasangan bronjong juga perlu dilakukan guna menahan pergerakan tanah sehingga mencegah terjadinya longsor pada daerah yang rawan. Mitigasi non struktural yang dapat dilakukan seperti memberikan sosialisasi tentang bahaya longsor, menjelaskan secara terperinci keadaan tanah dan kondisi permukaan lereng kepada masyarakat sekitar yang berada pada daerah rawan longsor hal itu berguna untuk menyadarkan masyarakat sekitar untuklebih peka dan menjaga lingkungannya. Mengadakan pelatihan-pelatihan yang berkaitan dengan evakuasi bencana saat terjadinya bencana longsor dan membentuk forum relawan bencana untuk meringankan beban masyarakat yang terkena bencana tanah longsor.

\section{Kesimpulan}

Berdasarkan hasil analisis dari penilitian ini, maka dapat ditarik kesimpulan sebaran rawan longsor di Kecamatan Berastagi terjadi secara merata pada tiap desa dengan klasifikasi kerawanan tinggi diantarnya Desa Doulu, Desa Sempajaya, Desa Raya, Desa Tambak Lau Mulgap II dan Desa Rumah Berastagi, dengan luas area yang berpotensi terjadinya longsor berkisar 233,37 Ha. Sedangkan luas area yang berpotensi terjadinya longsor dengan klasifikasi tinggi berkisar 837,54 Ha. Faktor pemicu terjadinya longsor disebabkan oleh kemiringan lereng yang curam hingga sangat curam disertai curah hujan tinggi di Kecamatan Berastagi.

\section{Daftar Pustaka}

[1] Noor, D., Geologi Untuk Perencanaan, Graha Ilmu. Yogyakarta, 2011.

[2] Sideng. U., Maru. R., Nyompa. S., Arfan. A., Malik. A., dan Abidin. M. R, Mapping and Zonation Level of Landslides Hazard and Risk Assessment: A Case Study of Enrekang Regency, South Sulawesi, Indonesia, Environment Asia,Vol. 11(2), pp. 149-163, 2018.

[3] Zhao. C. and Lu.Z. Remote Sensing of Landslides-A Review. Remote Sens. 2018, 10, 279: 1-6. DOI:10.3390/ rs10020279. 2018

[4] Arsyad, U., Barkey, R., Wahyuni, dan Matandung, K, "Karakteristik Tanah Longsor di Daerah Aliran Sungai Tangka,"J.Hutan dan Masyarakat. Vol. 10 (1), hal.203-214, 2018. DOI: http://dx.doi.org/10.24259/jhm.v0i0.3978

[5] Sharma, L. P.Nilanchal Patel, P. Debnath, M. K. Ghose, "Assessing landslide vulnerability from soil characteristics-a GIS-based analysis,"Arab J.Geosci., 5:789-796, 2010. DOI $10.1007 / \mathrm{s} 12517-010-0272-5$

[6] Jen Chang. K., Chang Chan. Y., Fei Chen. R., dan Chung Hsieh.Y. "Geomorphological Evolution Of Landslides Near An Active Normal Fault In Northern Taiwan, As Revealed By Lidar And Unmanned Aircraft System Data,"Nat. Hazards Earth Syst. Sci., 18, 709-727, 2018. https://doi. org/10.5194/nhess-18-709-2018

[7] Arsyad, U., Barkey, R., Wahyuni, dan Matandung, K. 2018. Karakteristik Tanah Longsor di Daerah Aliran Sungai Tangka. Jurnal Hutan dan Masyarakat. Vol. 10 (1), 203-214. DOI: http://dx.doi.org/10.24259/jhm.v0i0.3978

[8] Nugroho, S. P. Evalusi Penanggulangan Bencana 2015 dan Prediksi Bencana 2016. Jakarta: BNPB. 2016

[9] Muchlis. Interpretasi Potensi Massa Longsoran Dengan Metoda Geolistrik (Studi Kasus Daerah Gayo Lues). Jurnal Natural, 15(1), 16-18. 2015

[10] Pusat Vulkanologi dan Mitigasi Bencana Geologi. Gerakan Tanah, Kementrian ESDM, Bandung. 2013

[11] Pusat Vulkanologi dan Mitigasi Bencana Geologi. Prakiraan Wilayah Potensi Terjadi Gerakan Tanah/Tanah Longsor dan Banjir Bandang di Seluruh Indonesia. Bandung: ESDM, Kementerian. (2015). 
[12] Sipayung, S. B., Cholianawati, N., Susanti, I., Aulia, S., Edy, R., Pusat, P., \& Atmosfer, T. (2014). Pengembangan Model Persamaan Empiris Dalam Memprediksi Terjadinya Longsor di Daerah Aliran Sungai (DAS) Citarum (Jawa Barat) Berbasis Data Satelit TRMM. Jurnal Sains Dirgantara, 12(1), 12-21.

[13] Suriadi, A. B., Arsjad, M. dan Hartini, S. (2014). Analisis Potensi Risiko Tanah Longsor di Kabupaten Ciamis dan Kota Banjar, Jawa Barat. Majalah Ilmiah Globe, 16, 165-172.

[14] Setiadi T. (2013). Perancangan Sistem Informasi Geografis Pemetaan Daerah Rentan Tanah Longsor, Mitigasi dan Manajemen Bencana di Kabupaten Banjarnegara. Kesmas, 7(1), 33-42.

[15] Anwar, A. (2012). Pemetaan Daerah Rawan Longsor Di Lahan Pertanian Kecamatan Sinjai Barat Kabupaten Sinjai. Retrieved from http://repository.unhas.ac.id/handle/123456789/2896 